\title{
Investigating the Science Process Skills in Cycle 3 National Science Textbooks in Lebanon
}

\author{
Samar Zeitoun*, Zeina Hajo \\ Faculty of Education, Lebanese University, Beirut, Lebanon \\ *Corresponding author: szeitoun99@hotmail.com
}

Received January 03, 2015; Revised February 09, 2015; Accepted February 25, 2015

\begin{abstract}
The purpose of this study is to examine the level of inclusion of basic and integrated science process skills in Lebanese national science text books for cycle 3 and to compare the basic and integrated process skills across subjects (physics, chemistry and biology) and within the same subject across the 3 years(grades 7, 8 \& 9). This was to investigate the compliance between the content of the textbooks and the new evaluation system set by the Lebanese government. For instance, the study focused on the SPS that have been neglected in some textbooks as well as the maximum percentage of each skill. To that end, the researchers used the analytical descriptive method, and content analysis. The study revealed that the percentage of basic skills in the textbooks analyzed for all grades was higher than that of the integrated skills. The study revealed also that there is emphasis on some skills at the expense of the others and there is no consistency in the total number of skills across skills or subjects. Furthermore the study revealed that within the same subject, some skills disappear from one grade to another. The study ends by recommendations regarding reviewing textbooks regarding the inclusion of science process skills in a way to ensure coherence between the content of the textbooks and the new evaluation system.
\end{abstract}

Keywords: science process skills, Lebanon, science books, basic, integrated

Cite This Article: Samar Zeitoun, and Zeina Hajo, "Investigating the Science Process Skills in Cycle 3 National Science Textbooks in Lebanon.” American Journal of Educational Research, vol. 3, no. 3 (2015): 268275. doi: 10.12691/education-3-3-3.

\section{Introduction}

Lebanese students lag behind in math and science study (Boujaoude, 2007). The national and international assessment results indicated that Lebanese students' conceptual understanding in science and basic inquiry skills are far behind the expected levels. Eighth-grade school children in Lebanon perform below the international average in mathematics and science (HSRC, 2012; MEHE, 2010). On TIMSS, Lebanon is ranked $28^{\text {th }}$ in the classification of the results of Mathematics (2007) for grade 8 , and is ranked $40^{\text {th }}$ in the results of Science, which is below the international average for both subjects. Furthermore, the public sector students' levels are $10 \%$ less than those of their counterparts in the private sector (MEHE, 2010). Furthermore, according to Boujaoude (2007), curricula in twenty-first century effort-based schools cannot continue to focus on old basics. Critical thinking and problem-solving should be the new basics in the new millennium. It is impossible to teach content without teaching thinking skills and thinking skills without content (Boujaoude, 2007).

To achieve the aims and objectives of the new program launched in 1997, a new educational strategy is adopted in Lebanon. The new curricula emphasized a shift from teacher-centred method of teaching science to learner centred activity based method which encourages and develops the spirit of inquiry. This strategy aims to provide the learner with a set of values, knowledge, skills and modern scientific knowledge and positive attitudes vis-à-vis sciences (NCERD, 1997). This strategy takes into account, on the one hand, the assimilation by the learner, of the knowledge, definitions, application, analysis and synthesis, to the extent permitted by the discipline in question and the physical, intellectual and language skills of the learner; on the other, it accounts for the current and future needs of the labour markets. All this should facilitate the development of scientific skills that will enable the learner to understand and interpret the world around them and become a productive member of society (NCERD, 1997).

Furthermore, the general aims of teaching science as set by the NCERD (NCERD, 1997) are to make students understand the ways scientists work and to equip and to prepare them for their possible careers in science and technology. All this led to the development of process skills (NCERD, 1997). In the new curricula implemented by the Ministry of Education in Lebanon, the idea of literacy in science and technology is emphasized in several categories one of which is the science process skills. The curriculum requires that students use the science process skills during decision making and problem solving allowing them to draw conclusions and conduct investigations.

Science process skills have been described as mental and physical abilities and competencies which serve as 
tools needed for improvements in problem solving, technology as well as individual and societal development (Ozgelen, 2012). They can also be perceived as the adaptation of the skills used by scientists for composing knowledge thinking about problems and drawing conclusions. Nevertheless, all definitions provided to science process skills agreed that on those skills facilitating basic activities as learning science, gaining research methods, helping students to become active and making learning permanent (Chiapetta \& Fillman, 2007; Padilla, 1990). These skills are cognitive and psychomotor skills employed in problem solving. They are the skills which scientists use in problem-identification, objective inquiry, data gathering, transformation, interpretation and communication. Using science process skills is an important indicator of transfer of knowledge which is necessary for problem-solving and functional living. Those skills provide meaningful learning and prevent memorization of facts and developing negative attitudes to science (Cain, 2002). They have also great influence on education because they help students develop mental processes such as problem solving, critical thinking and making decisions (Cheng, 2004). This is perceived by Lebanese stakeholders as an essential in succeeding at international tests such as TIMSS where Lebanese students had poor achievements. In the new programs implemented by the Ministry of Education in Lebanon, the idea of literacy in science and technology is emphasized in several categories, one of which is the scientific skill. The program requires that students use these skills in decision making and problem solving by allowing them to draw conclusions and to investigate. The importance of these skills lies in that they are defined as adapting skills used by scientists to make assumptions about the problems and draw conclusions.

Science process skills (SPS) are classified into basic and integrated. The basic science process skills are useful in science and non-science situations while the integrated skills are the working behaviour of the scientists and technologists. Thus, both basic and integrated science process skills are relevant and appropriate for all science subjects. Hence, there is need to find out the level of presence of the science process skills in curricula and books and classify them to various hierarchical levels.

The purpose of this study is to determine the science process skills included in the science textbooks issued by the NCERD for cycle 3 in Lebanon; that is, the 9 science textbooks for the 3 subjects: biology, chemistry and physics. The study is important as it is perceived that the benefits of school textbooks as classroom resources are seldom queried. Textbooks are often described as the tools of the teachers' trade and as a means for spreading knowledge (Kamm \& Taylor, 1966) and acting as the primary source of knowledge for most students (Gottfried \& Kyle, 1992). The textbook is, in fact, the heart of the school and without the ubiquitous text there would be no schools, at least as we know them (Ian Westbury, cited in Oakes \& Saunders, 2004). A study in the UK has confirmed the direct relationship between expenditure on textbooks and learners' achievement (Watson, 2000). Linked to this, Haggarty \& Pepin (2002) have raised a concern about the restricted access that pupils in England have to mathematics textbooks and the resultant impact on learning outcomes.
The textbook is unanimous about its key role in education. It not only contributes to education through the dissemination of knowledge, but also to skills and attitudes, by transmitting more or less explicit, model social behavior, norms and values. That's why the textbook is both a teaching tool and a tool for social change. For the developing world, international surveys show that the provision of textbooks ranks amongst the five most cost-effective ways of improving achievement of learners (Verspoor, 1991; Heynemen, 2006). BouJaoude (2002) further argues that the emphasis on the interaction of science, technology, and society in the Lebanese curriculum holds the potential for the development of citizens and decision makers who use scientific knowledge meaningfully in their lives. However, he cautions, "Teaching, assessment, and the quality of textbooks used are also important factors that need to be considered if students' experience with science is to be complete and fulfilling”' (BouJaoude, 2002, p. 154).

This research will have an impact on science education in Lebanon as it aims to provide significant results for the ability to improve teaching and learning science. It is designed to establish a synergistic relationship between research and practice in order to make results accessible, understandable, meaningful and relevant for teachers, administrators and policy makers. It examines the issues that are relevant to improving science teaching and learning for all students which have not been studied or understudied.

The research questions are:

What are the percentages of basic and integrated science process skills in the Lebanese national science textbooks for cycle 3?

Are these skills distributed equally in the 9 books or vary depending on discipline and grade level?

The study is designed to achieve the following objectives:

- $\quad$ Compare the basic and integrated process skills included in the Lebanese textbooks issued by the National Center for Educational Research and Development in the three different subjects: Biology, Chemistry and physics.

- Examine the level of inclusion of basic and integrated science process skills in Lebanese national science text books for cycle 3 issued by the National Center for Educational Research and Development for cycle 3 in Lebanon.

- $\quad$ Determine the science process skills (SPS), that have been neglected in some textbooks as well as the maximum percentage of each science process skill for the three subjects (physics, chemistry and biology) across the three years in cycle 3 : grades 7,8 and 9 .

\section{Methodology}

To achieve the goals of the study, a measuring instrument was developed, based on content analysis framework, to analyze the content of nine science textbooks (grades 7, 8 and 9) according to science process skills (Table 1 ). The two researchers examined the various national and international benchmarks to establish definitions for each skill. The measuring instrument is a form that includes definitions for each element of the SPS 
supported by examples relevant to the textbooks' content and on which the 3 coders agreed. This instrument was prepared based on a system of categories covering all aspects relevant to answer the research questions.
Different meaning units (propositions) are then assigned to different categories already identified theoretically on basic and integrated skills (Chiapetta \& Koballa, 2010, Abruscato, 2004; Martin et al., 2009).

Table 1. Science process skills in Lebanese national textbooks (Chiappetta \& Koballa, 2010; Padilla, 1990; AAAS, 1993, NCERD, 1999)

\begin{tabular}{|c|c|c|c|c|}
\hline Skill & Definition & Example physics & Example chemistry & Example biology \\
\hline Observe & $\begin{array}{l}\text { The process of using the five senses to gather } \\
\text { information about an object or event }\end{array}$ & $\begin{array}{l}\text { Does their shape change } \\
\text { when displaced }\end{array}$ & What is the color & $\begin{array}{l}\text { indicate the consumed } \\
\text { food is of animal }\end{array}$ \\
\hline Classify & $\begin{array}{l}\text { The process of grouping or ordering objects or } \\
\text { events into categories }\end{array}$ & $\begin{array}{c}\text { Classify the objects as } \\
\text { conductors and } \\
\text { insulators } \\
\end{array}$ & $\begin{array}{l}\text { Classify the following } \\
\text { substances as solids, } \\
\text { liquids }\end{array}$ & $\begin{array}{l}\text { Classify animals } \\
\text { according to diet }\end{array}$ \\
\hline Infer & $\begin{array}{c}\text { The process of making suggestions, } \\
\text { conclusions, assumptions, or explanations about } \\
\text { a specific event based on observation and data }\end{array}$ & What Can you conclude & $\begin{array}{l}\text { Why filtration is an } \\
\text { efficient technique }\end{array}$ & $\begin{array}{l}\text { Indicate the food diet } \\
\text { based on doc } d \text { and } f\end{array}$ \\
\hline Compare & $\begin{array}{l}\text { The process of indicating the similarities and/or } \\
\text { differences between two or more entities. }\end{array}$ & $\begin{array}{l}\text { Does this ratio have } \\
\text { same value }\end{array}$ & $\begin{array}{c}\text { Compare the } \\
\text { characteristics } \\
\text { Compare } \mathrm{pH} \text { values }\end{array}$ & Compare the values \\
\hline Measure & $\begin{array}{l}\text { The process of using standard and nonstandard } \\
\text { measures or estimates and their appropriate } \\
\text { instruments to describe the dimensions of an } \\
\text { object, substance, or event in quantitative terms }\end{array}$ & $\begin{array}{l}\text { What is the volume of } \\
\text { displaced water }\end{array}$ & $\begin{array}{l}\text { What is the observed: } \\
\text { Melting point } \\
\text { Freezing point } \\
\text { Take pH of water }\end{array}$ & $\begin{array}{l}\text { estimate the } \\
\text { respiratory frequency }\end{array}$ \\
\hline Use numbers & $\begin{array}{l}\text { It is the process of using quantitative } \\
\text { relationships }\end{array}$ & $\begin{array}{l}\text { calculate the area of the } \\
\text { base }\end{array}$ & $\begin{array}{l}\text { Calculate the number of } \\
\text { moles }\end{array}$ & $\begin{array}{l}\text { Calculate the energy } \\
\text { value of foods }\end{array}$ \\
\hline Communicate & $\begin{array}{l}\text { The process of using words, symbols, graphics, } \\
\text { diagrams, graphs, tables and figures and other } \\
\text { written or oral representations to describe and } \\
\text { exchange information, such as an action, object } \\
\text { or event, from one person or system to another }\end{array}$ & $\begin{array}{l}\text { What is the relation } \\
\text { between mass, volume } \\
\text { and density }\end{array}$ & $\begin{array}{l}\text { Draw the structural } \\
\text { formula }\end{array}$ & $\begin{array}{l}\text { Refer to doc (pie } \\
\text { chart) indicate }\end{array}$ \\
\hline Predict & $\begin{array}{c}\text { Stating the outcome of a future event based on a } \\
\text { pattern of evidence, past experience, or } \\
\text { observations }\end{array}$ & $\begin{array}{l}\text { What will happen to the } \\
\text { air in the balloon }\end{array}$ & $\begin{array}{c}\text { How will the charged } \\
\text { objects interact }\end{array}$ & $\begin{array}{l}\text { How do we recognize } \\
\text { the food diet of an } \\
\text { animal? }\end{array}$ \\
\hline Experiment & $\begin{array}{l}\text { carrying out an experiment by carefully } \\
\text { following directions of the procedure so the } \\
\text { results can be verified by repeating the } \\
\text { procedure several times }\end{array}$ & $\begin{array}{l}\text { Take a vessel } \\
\text { Attach a plumb line }\end{array}$ & \begin{tabular}{|} 
Prepare \\
Dip, \\
pour
\end{tabular} & 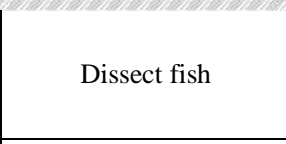 \\
\hline Interpret & $\begin{array}{c}\text { The process of treating or transforming data } \\
\text { through finding patterns, graphs, or tables in } \\
\text { order to make it meaningful and draw } \\
\text { conclusions from it }\end{array}$ & $\begin{array}{l}\text { Are water alcohol milk } \\
\text { liquids } \\
\text { Do these two } \\
\text { experiments }\end{array}$ & $\begin{array}{l}\text { In which case is the } \\
\text { combustion complete } \\
\text { What does the conductivity } \\
\text { of vinegar or sodium } \\
\text { hydroxide indicate? } \\
\end{array}$ & $\begin{array}{l}\text { do the results of the } \\
\text { expts confirm hypo }\end{array}$ \\
\hline $\begin{array}{l}\text { Formulate } \\
\text { model }\end{array}$ & $\begin{array}{c}\text { The process of creating a mental, pictorial, } \\
\text { written or physical representation to explain an } \\
\text { idea, object, or event }\end{array}$ & & Build model of ethane & \\
\hline $\begin{array}{c}\text { Design } \\
\text { experiment }\end{array}$ & $\begin{array}{l}\text { The process of determining and executing } \\
\text { reasonable procedures to test an idea or } \\
\text { hypothesis using observation, identifying and } \\
\text { controlling variables, collecting and interpreting } \\
\text { data, measuring, and manipulating materials }\end{array}$ & & & Plan experiment \\
\hline Out & $\begin{array}{l}\text { The answer is yes or no } \\
\text { Or students cannot figure the answer on their } \\
\text { own }\end{array}$ & $\begin{array}{l}\text { Does this activity show } \\
\text { that air has volume } \\
\text { Does the motion of balls } \\
\text { resemble that of dust } \\
\text { particles }\end{array}$ & $\begin{array}{c}\text { the chemical equation } \\
\text { (without explaining basics) } \\
\text { name products }\end{array}$ & $\begin{array}{l}\text { why cannot it be } \\
\text { external }\end{array}$ \\
\hline
\end{tabular}

The analysis of the content of new science textbooks (physics, chemistry and biology in the (grades 7, 8 and 9), using the instrument is based on an extensive method (analysis of a large number of information) in order to measure the frequency of occurrences of skills in the books and the relationships between them. This categorical analysis (quantitative) aimed to calculate and compare the frequencies of skills, grouped into meaningful categories (basic and integrated).

The sample for this study includes all units of textbooks and activities, but it does not include the objectives and the evaluation exercises at the end of chapters. To perform a content analysis on such a text, the text was coded or broken down into manageable categories on a variety of levels as a word, phrase, sentence, or theme. In this study, a theme was adopted as a class to analyze the content of textbooks (Krippendorff, 2004; Al-Ashwal, 2006; Aziz, 2004; Krippendorff, 2004; Shaker, 2005).
This type of coding is conceptualized based on a list of predefined themes which allowed the designation of a word (or sentence or words) from textbooks (inductive coding). Then to confirm themes, researchers took similar or related labels, in order to purify and stabilize the themes to ensure semantic irreducibility. The 9 science textbooks were organized in different forms since they were written by different sets of authors. Since this study is based on a quantitative approach, inconsistency in the analysis of textbooks' content in uniform theme will have a negative effect on the results of the study. To avoid this problem, a dedicated research assistant ${ }^{1}$ organized the textbooks into uniform topics under the supervision of researchers. The researchers and the research assistant met several times to organize the contents of each textbook.

Reliability requires the use of standardized instruments for data collection and survey methods that are designed

\footnotetext{
${ }^{1}$ Research assistant: Hanin Fuddah, PhD student, Lebanese University.
} 
to improve uniformity. For information to be relevant, one must be careful that the information is clearly linked to the objectives of the study. To obtain information that is complete and accurate, we need data collection instruments and methods of investigation that are well planned. Among the types of credibility- dependability, transferability and confirmability, reproducibility is probably the most feasible (Krippendorff, 2004); this ensures that the coding instrument will provide the same results with an acceptable margin of error. The key to reliability is the observed agreement among independent observers. Weber (1990) note: "To make valid inferences from the text, it is important that the classification procedure be reliable in the sense of being consistent: Different people should code the same text in the same way" (p. 12). As Weber further notes, "reliability problems usually develop on the ambiguity about the meaning of words, category definitions, or other coding rules" (p. 15). The two researchers with the assistant who developed the coding instrument (meter) worked closely on the project to establish common meanings and hidden coding. They analyzed the same book simultaneously. They started by grade 7 manuals. Each researcher individually classified the different themes of the first unit of the manual. Researchers then met after the analysis of each chapter to reconcile difference in categorization and consistency. For the grades 8 and 9, the analysis of each subject was carried out by 2 coders and Intercoder reliability was calculated to measure the congruence between coders. The percentage of agreement among coders ranged from 0.85 to 0.89 which showed a high degree of agreement among raters.

Once all the issues are sorted, the statistical analysis of the identified skills was carried out using computer wizard to extract their frequencies and percentages (Krippendorff, 2004). Based on the results, the researchers determined the level of inclusion of basic and integrated skills in the national school science textbooks for cycle 3 and compared those skills over the three years of the cycle 3 for the same discipline and among the three disciplines.

\section{Results}

Descriptive statistics enable the researchers to meaningfully describe a distribution of measurements and summarize data.

\subsection{Distribution of skills across subjects}

\section{a. Chemistry}

The following chart shows the distribution of skills in chemistry across the three grades:

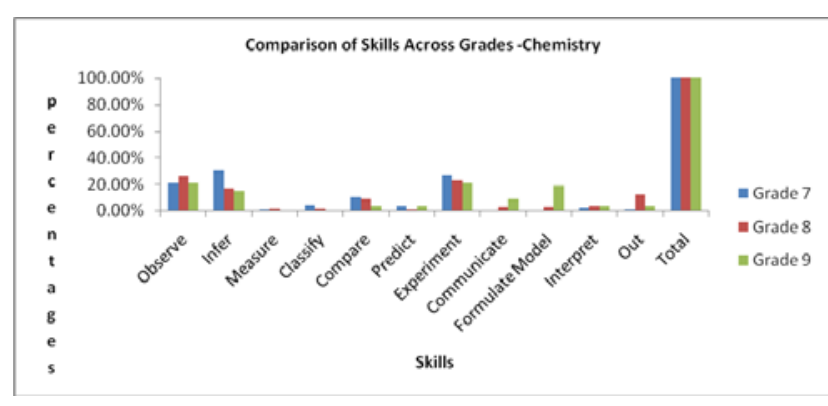

The results show a decrease in the total number of skills from grade 7 to grade 9 .

The total number of skills for chemistry grade 7 is 155 (of which 110 basic, 45 integrated) and 1 question out grade 8 is 169 skills (of which 113 basic and 56 integrated) and 23 out - grade 9 is 77 (of which 42 basic and 35 integrated) and 3 out.

\begin{tabular}{|c|c|c|c|c|}
\hline Chemistry & Basic & Integrated & Total & Out \\
\hline G7 & $71 \%$ & $29 \%$ & 155 & 1 \\
\hline G8 & $59 \%$ & $41 \%$ & 169 & 23 \\
\hline G9 & $53 \%$ & $47 \%$ & 77 & 3 \\
\hline
\end{tabular}

Although the total number of skills decreased from grade 7 to grade 9 (155 to 80 ), the percentage of integrated skills in chemistry increased from $29 \%$ to $47 \%$.

The skill "use numbers" is completely absent in chemistry content, and the skills "observe" and "experiment" have the highest frequency (25\%). Some skills disappear completely in grade 9 such as "measure" and "classify", others are not found in grade 7 such as "communicate" and "formulate models".

Correlations

\begin{tabular}{|ll|l|l|}
\hline & & Basic Skills & Integrated skills \\
\hline \multirow{3}{*}{ Basic Skills } & Pearson Correlation & 1 & -.1 \\
& Sig. (2-tailed) & & .048 \\
& $\mathrm{~N}$ & 3 & 3 \\
\hline \multirow{2}{*}{ Integrated skills } & Pearson Correlation & -1 & 1 \\
& Sig. (2-tailed) & .048 & \\
& $\mathrm{~N}$ & 3 & 3 \\
\hline
\end{tabular}

*. Correlation is significant at the 0.05 level (2-tailed).

The Pearson correlation coefficient calculated to show correlation between basic and integrated skills across the 3 years. The Pearson correlation coefficient is $=-1$ which means that there is a perfect negative correlation between the 2 variables (basic skills and integrated skills) among grades 7, 8, and 9 in Chemistry subject.

In another sense, it indicates that basic skills and integrated skills are perfectly related in a negative or inverse linear sense.

\section{b. Physics}

The following chart shows the distribution of skills in physics across the three grades

\section{Comparison of Skills Across Grades-Physics}

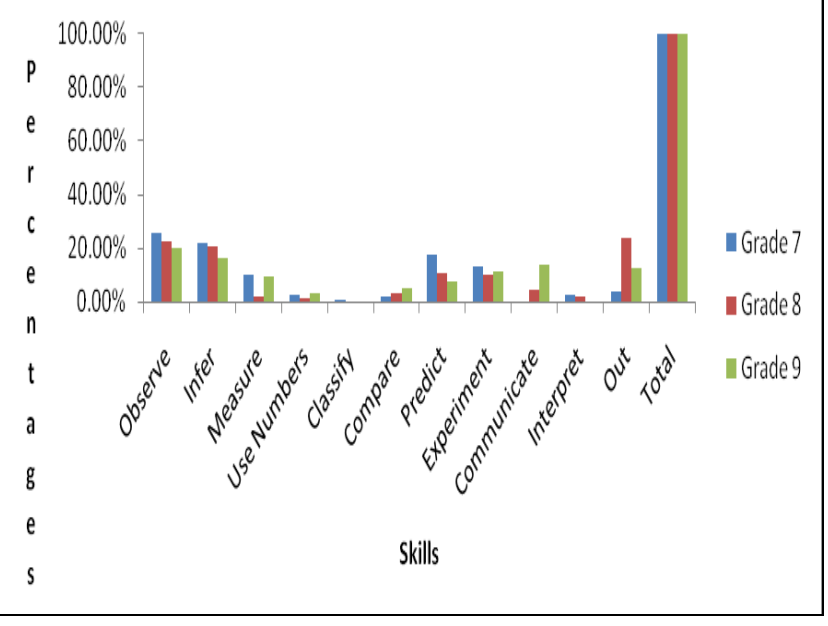

The total number of skills for grade 7 is 333 skills (of which 278 basic and 55 integrated) and 14 out, for grade 8 
is 363 skills (of which 308 basic and 55 integrated) and 115 out, and for grade 9 is 506 skills (of which 437 basic and 69 integrated) and 72 out.

\begin{tabular}{|c|c|c|c|c|}
\hline Physics & Basic & Integrated & Total & Out \\
\hline G7 & $83.5 \%$ & $16.5 \%$ & 333 & 14 \\
\hline G8 & $85 \%$ & $15 \%$ & 363 & 115 \\
\hline G9 & $86.4 \%$ & $13.6 \%$ & 506 & 72 \\
\hline
\end{tabular}

The skills with highest percentage is "observe" and "infer" (22\%) and the lowest is and "use numbers (3\%) and "interpret"(2.88\%). The skill "classify" (0.58\%) is absent in grades 8 and 9.

The Pearson correlation coefficient calculated for physics across the 3 grades:

Correlations

\begin{tabular}{|ll|l|l|}
\hline & & Basic skill & Integrated skills \\
\hline \multirow{3}{*}{ Basic skill } & Pearson Correlation & 1 & .706 \\
& Sig. (2-tailed) & & .501 \\
& $\mathrm{~N}$ & 3 & 3 \\
\hline \multirow{3}{*}{ Integrated skills } & Pearson Correlation & .706 & 1 \\
& Sig. (2-tailed) & .501 & \\
& $\mathrm{~N}$ & 3 & 3 \\
\hline
\end{tabular}

The coefficient of correlation is equal to 0.706129 and since it is positive and closer to 1 , we can conclude that there is a direct relationship or strong positive association between the basic skills and integrated skills among grades 7, 8, and 9 in Physics subject.

\section{c. Biology}

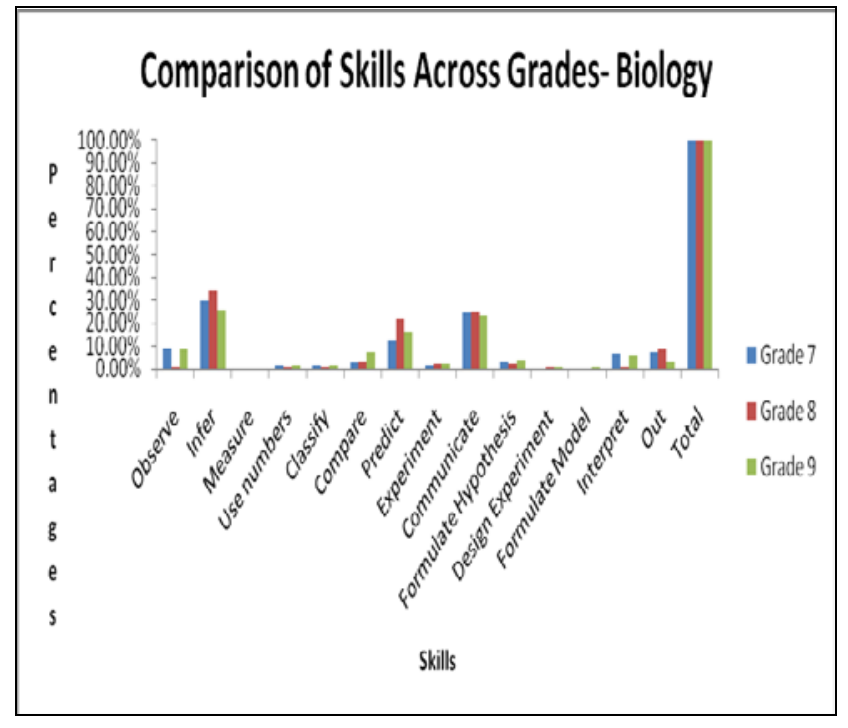

The total number of skills for Biology grade 7 is 507 skills (of which 442 basic and 65 integrated) and 40 out, for grade 8 is 195 skills (of which 185 basic and 10 integrated) and 18 out, for grade 9 is 375 skills (of which 324 basic and 51 integrated ) and 12 out.

\begin{tabular}{|c|c|c|c|c|}
\hline Biology & Basic & Integrated & Total & Out \\
\hline G7 & $87 \%$ & $13 \%$ & 507 & 40 \\
\hline G8 & $95 \%$ & $5 \%$ & 195 & 18 \\
\hline G9 & $86.4 \%$ & $13.6 \%$ & 375 & 12 \\
\hline
\end{tabular}

The skills with highest percentage in biology are "infer" and "communicate" (31\%) and the least is "formulate model" and "design experiment". The skill "measure” is completely absent in grades 8 and 9, whereas the skill "formulate model" is absent in grades 7 and 8 .

The Pearson correlation coefficient was used to verify the inconsistency in the number of basic and integrated skills in biology across the grades.
Correlations

\begin{tabular}{|ll|l|l|}
\hline & & Basic skill & integrated skill \\
\hline \multirow{4}{*}{ Basic skill } & Pearson Correlation & 1 & -.793 \\
& Sig. (2-tailed) & & .417 \\
& $\mathrm{~N}$ & 3 & 3 \\
\hline \multirow{4}{*}{ integrated skill } & Pearson Correlation & -.793 & 1 \\
& Sig. (2-tailed) & .417 & \\
& $\mathrm{~N}$ & 3 & 3 \\
\hline
\end{tabular}

The coefficient of correlation (Pearson correlation coefficient) $=-0.79342$ which is closer to -1 . That's why we notice there is a strong negative correlation between integrated skills and basic skills among grades 7, 8, and 9 in Biology Subject.

\subsection{Distribution of skills across grade levels}

\section{a. Grade 7}

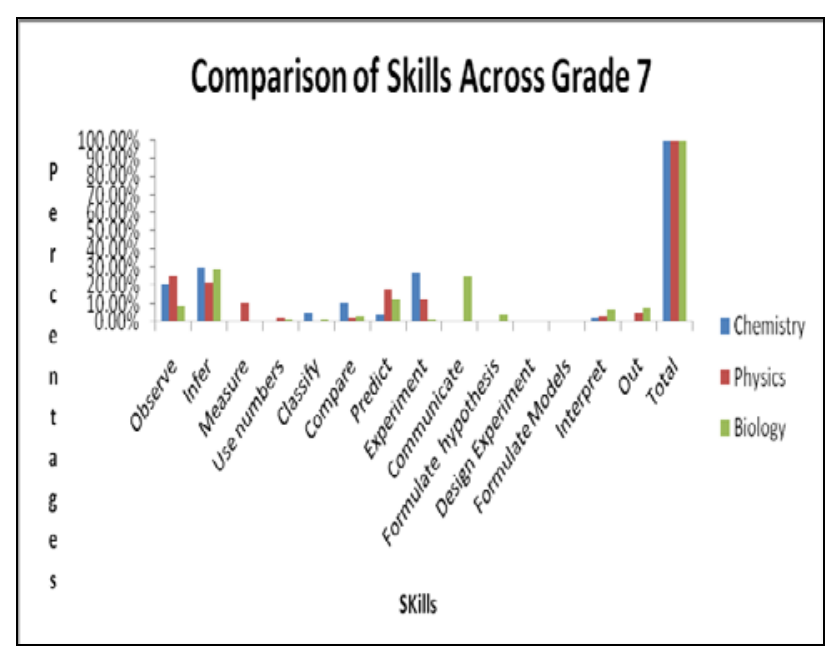

The skill "use numbers" is not found in chemistry whereas the skills "formulate hypothesis" and "design experiment" are found only in biology.

The most predominant skills for the 3 subjects are "observe" and "infer" and the least ones are "interpret" and "classify". The skills "design experiment" and "formulate models" are null for all subjects whereas "measure" is found only in physics, "communicate" and "formulate hypothesis" only in biology, whereas "experiment" predominates for chemistry, relative to physics and biology.

\section{b. Grade 8}

\section{Comparison of Skills Across Grade 8}

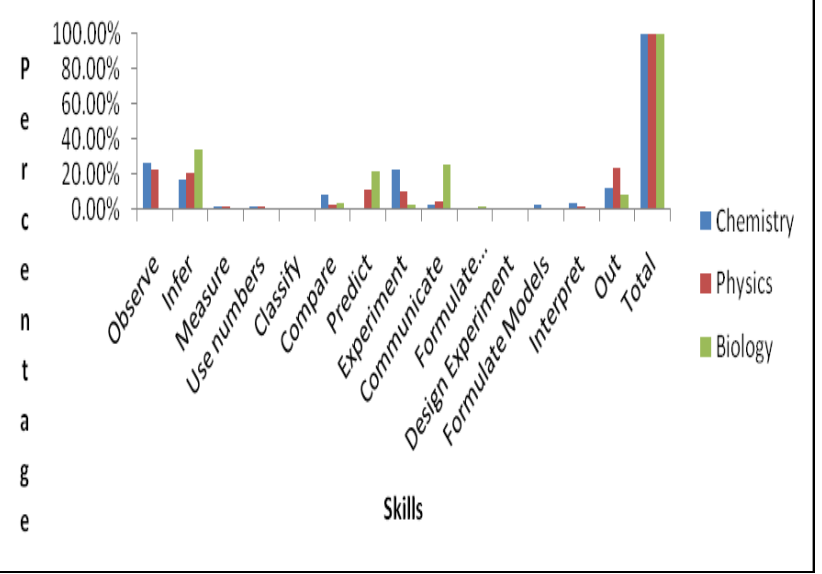


Also in grade 8, the most predominant skills are "observe" and "infer", the skills "design experiment" and classify" are null, whereas the skills ", the skills "measure" and "use numbers" have the least percentages. The graph also shows that "formulate models" is only found in chemistry whereas the skill "formulate hypothesis" is only found in biology.

\section{c. Grade 9}

For grade 9, the most prominent skills are "observe”, "infer" and "communicate" (mostly in biology and "experiment" mostly in chemistry. Only the skill "design experiment" is null, whereas for the skills "formulate models" is only found in chemistry, "formulate hypothesis" and classify only in biology and "measure" only in physics.

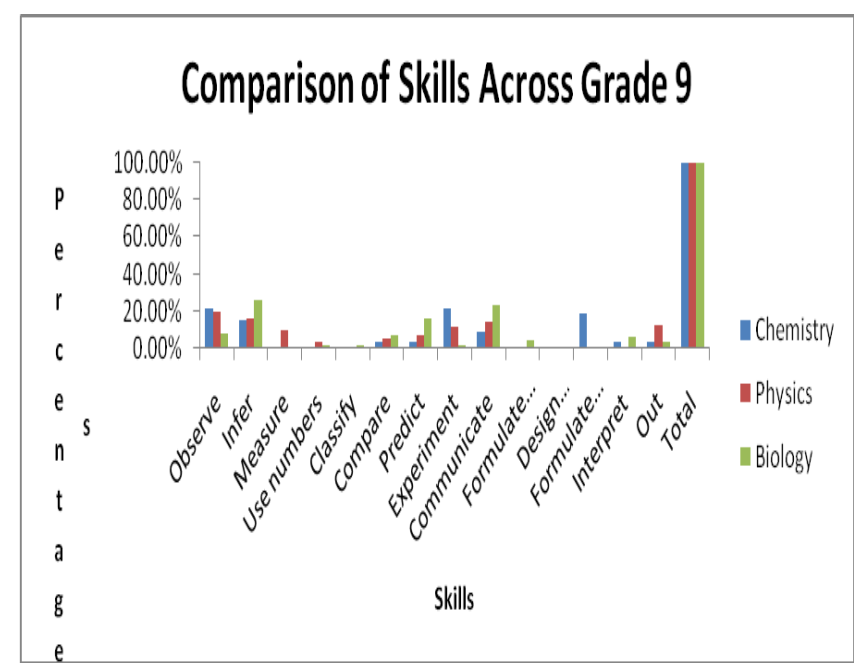

\section{Discussion}

\subsection{The Level of Inclusion of SPS in National Science Textbooks}

This study aimed to analyze the content of the national Lebanese science textbooks published by the NCERD regarding their content in SPS. The aim was to examine the degree of conformity between the content of the textbook and the guidelines of the new evaluation system based on competencies through 3 domains: applying knowledge, communication and experimentation. The e domains se describes in evaluation guides (NCERD, 1999) require explicit implementation of SPS. For example, the “applying knowledge domain” includes skills such as analyzing data, observing, applying appropriate knowledge and evaluating the validity of results. In the communication domain, the students are expected to draw out information from diagrams. The third domain requires students to experiment, explain phenomena by observation and hypothesizing (NECRD, 1999). The analysis shows the presence of a number of SPS across the grades and subjects. This is in line with the national education policy which aims at consolidating the science process skills knowledge. The analysis showed that, for all subjects and across the 3 grades, the basic skills are more frequent than the integrated skills. However, there is departure from a general pattern as the percentage of basic skills in chemistry decreased from grade 7 to grade 9 while that of integrated skills increased whereas for biology and physics the percentage of integrated skills remained almost the same.

The above analysis indicated that the new science curriculum lacked a coherent and well thought-out framework regarding science process skills. The Lebanese government set, in 1999, a new evaluation system based on evaluation of competencies and the NCERD published evaluation guides for all subjects and cycles. For example, one general objective of the new NCERD (1997) curriculum is to “develop learners' intellectual and practical scientific skills". This new evaluation system was considered as a significant step forward in the development of new curricula (NCERD, 1999). The "applying knowledge" domain included skills such as analyzing data, observing documents, applying appropriate knowledge and evaluating the validity of results. In the "communication" domain, the students are expected to draw out appropriate information from diagrams. Added to this are the domains of "conducting an experiment, explaining phenomena by observation and hypothesizing, and drawing charts or graphs". These competencies as defined by the NCERD were supposed to cover what is known as science process skills.

Data analysis showed that there is emphasis on certain skills, mostly basic ones in the contents of lessons and activities. Although the evaluation guides specified the process skills that teachers should address in their books, there is lack of coherence between the evaluation guides and the specific objectives of the books. Furthermore, the deficiency in the basic skills that set out to progressively develop students' further integrated skills cannot construct a rigid framework for an adoption of "the scientific method."

The reason for overemphasis on the basic skills could be due to the fact that these skills are easily learnt and transferable to novel situations unlike the integrated ones that require a series of consistent, multiple practical sessions. At the same time, the integrated science process skills require higher order cognitive abilities which might have not developed well or have not been allowed to grow in the learning environments.

The correlation coefficient when calculated for the chemistry subject showed a perfect negative correlation and for biology showed a negative correlation close to 1 . This indicated that as the number of basic skills decreased from grade 7 to grade 9 the percentage of integrated skills increased. In physics there is a positive correlation between basic and integrated skills.

\subsection{Comparison of Skills Across Subjects and Grades}

There is inconsistency in the total number of skills across the 3 grade levels for the same subject or across the same grade level for the 3 subjects. Chemistry has the least total number of skills for the 3 grades as compared to biology and physics whereas the highest total number of skills was for physics. In chemistry the total number of skills was the lowest for grade 9 (97) whereas in physics it was in grade 7 (333) and in biology in grade 8 (195).

The total number of skills decreased in chemistry from grade 7 to grade 9 whereas it has increased in physics. In biology the number dropped in grade 8 to rise again in grade 9 but remained less than that of grade 7 . 
While "observe”, "infer" and "experiment” are the most prominent skills in chemistry, "observe”, “infer", "predict" and "experiment" are the most prominent in physics and "predict", "infer" and "communicate” are the most prominent in biology. These findings can be explained that the skill "observe" is the most basic skill in science and is subsumed in all the integrated science process skills. This was followed by "inferring". The most probable explanation is that for every observation there is need for inference. The findings also show that the emphasis laid on laboratory experiments as stated by Berberoğlu et al. (2002) has not been ignored in this curriculum. Using our sense organs, we observe events and objects, and learn how the world around us is (TTSPS). "Science starts with observation" and drawing conclusions is "interpreting the results of an observation or experiment and making judgments (Tan and Temiz, 2003). This is why it is important to have "observe" and "infer" as prominent science process skills. In biology there was more emphasis on "communication”, as most of the activities deal with graphs and charts and documents.

The skills "measure”, "design experiment", "formulate hypothesis" and "classify" are almost null in chemistry, "classify”, "design experiment”, "formulate hypothesis" and "interpret" almost null in physics, "classify", "measure”, “design experiment”, and "formulate model”.

This result is expected as the basic science process skills provide a foundation for learning more complex skills. The ability to use integrated process skills is dependent on the knowledge of the basic skills. This also might be due to the fact that basic process skills can be easily learnt, and readily transferred to new situations unlike integrated process skills abilities that need to be practiced over a period of time and cannot be learned in the time specified to teach a specific science content in Lebanon.

\section{Conclusion and Recommendations}

The Committee on Science Learning defined science as "a body of knowledge" and also included "the process whereby that body of knowledge has been established." (Duschl et al., 2007, p.26).

The analysis showed that there is lack of equality among the science process skills which makes the current curriculum product-based one and not "Science as a Process Approach"; this does not provide students with sufficient opportunities to elicit the critical thinking.

The analysis revealed that there is emphasis on certain skills, mostly basic ones in the contents of lessons and activities. NCERD and education stakeholders should pay more attention to the inclusion and the diversification of the science process skills, to enable students to be prone to creativity, problem solving and reflective thinking. More emphasis must be placed on skills such as "designing experiments”, “formulating hypothesis”, “interpreting data" and "formulating models".

Although the evaluation guides specified the process skills that should be addressed in books, there is lack of coherence between the evaluation guides and the specific objectives and content of the books. Furthermore, there is deficiency in a lot of basic skills that set out to progressively develop students' further integrated skills.
This does not allow to construct a rigid framework for an adoption of "Science as Inquiry" or even "The scientific method".

It is expected that this research will have an impact on science education in Lebanon as it aims to provide significant results for improving teaching and learning by establishing a synergistic relation between theory and practice in order to make results accessible, understandable and meaningful for teachers and policymakers.

Regarding curricula and textbooks, the new national science curricula and the way they are expressed in textbooks must consider science process skills as the building blocks from which suitable science tasks are being constructed. Science content taught in science classrooms should be used as a mean to develop science process skills (Nyakiti et al, 2010). This in accordance with what Boujaoude suggested that the Lebanese science curriculum must address the "science as a way of knowing” aspect of scientific literacy (Boujoaude, 2002). This will also be in line with the new orientations of the Lebanese curricula about how educational programs should provide the learner with knowledge and skills, develop the scientific spirit and the values attached to it, enrich its terminological knowledge and knowledge of scientific and mathematical principles as specified by the objectives of the educational reform plan (NCERD, 1997).

The skill objectives should be emphasized in teachers' books to cover the science process skills to be used by teachers when necessary during lecturing (Dönmez \& Azizoğlu, 2010).

Regarding teachers, they are supposed to inculcate these science process skills to the learners and hence their conceptual understanding of those skills is critical. This study provides a background for further researcher on science teachers' knowledge of SPS and how they need to capitalize on opportunities in the activities normally done in the classroom. It also aims to invite partners involved in science teachers training such as the NCERD or the Directorate for guidance and orientation (DGO) to focus on teachers' knowledge and implementation of SPS.

\section{References}

[1] Abruscato, J. Teaching children science: Discovery methods for the elementary and middle grades (2nd ed.). Pearson Education, Boston, 2004.

[2] BouJaoude, S. Balance of scientific literacy themes in science curricula: The case of Lebanon. International Journal of Science Education, 2002. 24, 139-156. Retrieved online from: http://www.iemed.org/anuari/2007/aarticles/aBouJaoude.pdf.

[3] BouJaoude, S. (2007). Twenty-first century educational skills for development in the Mediterranean: Quality and curriculum relevance (pp. 82-89). In Med. 2007: 2006 in the EuroMediterranean Space. Barcelona, Spain: European Institute of the Mediterranean (IEMed).

[4] Cain, S. Sciencing. (4th ed). Upper Saddle River, NJ: Pearson Education. 2002.

[5] Cheng, V. M. Y. Developing physics learning activities for fostering student creativity in Hong Kong context. Asia-Pacific Forum on Science Learning and Teaching, 2004, 5 (2), Article 1. Online] http://www.ied.edu.hk/apfslt/v5_issue2/chengmy/.

[6] Chiapetta, E., Sethna, G., \& Fillman, D.. Do middle school life science textbooks provide a balance of scientific literacy themes? Journal of Research in Science Teaching, 1993, 30, 787-797.

[7] Chiappetta, E. L., \& Fillman, D. A. Analysis of five high school biology textbooks used in the united states for inclusion of the 
nature of science. International Journal of Science Education,2007, 29 (15), 1847-1868.

[8] Chiappetta, E. L., \& Koballa, T. R., Jr. Science instruction in the middle and secondary schools ( $7^{\text {th }}$ ed.). Upper Saddle River, Allyn and Bacon, 2010.

[9] Fraenkel, J. R., \& Wallen, N. E. How to design and evaluate research in education with PowerWeb (6th ed.). McGraw-Hill. New York, 2006.

[10] Gottfried, S.S., \& Kyle, W.C. Textbook use and the biology education desired state. Journal of Research in science Teaching, 1992, 29, 35-49.

[11] Haggarty, L. and Pepin, B. An investigation of mathematics textbooks and their use in English, French and German Classrooms: who gets an opportunity to learn what? British Educational Research Journal, 2002, 28 (4), 567-90.

[12] Heyneman, S. P. The Effectiveness of Development Assistance in the Field of Education. Journal of International Cooperation in Education, 2006, 9 (1), 7-25.

[13] Human Science Research Council. Towards Equity and Excellence. Highlights from TIMSS 2011. 2012. Retrieved from http://www.hsrc.ac.za/uploads/pageContent/2929/TIMSSHighlight s2012Dec7final.pdf.

[14] Kamm, A., \& Taylor, B. Books and the teacher. University of London Press, London, 1996.

[15] Krippendorff, K. Content analysis: An introduction to its methodology. Sage, Thousand Oaks, CA, 2004.

[16] Lockheed, M. E., \& Verspoor, A. (1991). Improving primary education in developing countries. Washington, D.C: Published for the World Bank, Oxford University Press.
[17] Ministry of Education and Higher Education (2010). Quality Education for Growth. National Education Strategy Framework. Retrieved online from:

http://www.mehe.gov.lb/uploads/file/ESDP\%20modified\%20marc h\%202010/ESDP\%20English\%20FINAL\%20-p\%201.pdf.

[18] National Center for Educational Research and Development. Khotat al'nohoud al'tarbawi [National educational plan]. Beirut, Lebanon: Author, 1994.

[19] National Center for Educational Research and Development. Manahej al-ta'alim al-a'am wa ahdafaha [Public educational curricula and goals]. Beirut, Lebanon: Author, 1997.

[20] Nyakiti, C. Mwangi, J. \& Koyier, C. Mastering PTE science. Oxford University Press, Nairobi, 2010.

[21] Oakes, J. \& Saunders, M. Education’s most basic tools: Access to textbooks and instructional materials in California's public schools. Teachers College Record, 2004, 106 (10), 1967-1988.

[22] Ozgelen, S. Scientists' science process skills within a cognitive domain framework. Eurasia Journal of Mathematics, Science \& Technology Education, 2012, 8, 283-292.

[23] Heynemen, S. (2006). The role of textbooks in a modern system of education: towards high quality education for all. Retrieved from: http://www.vanderbilt.edu/peabody/heyneman/PUBLICATIONS/r oleoftextbooks.3.07.pdf.

[24] Padilla, M. J. (1990), Science Process Skills. National Association of Research in Science Teaching Publication: Research Matters to the Science Teacher (9004). Retrieved from National Association of Research in Science Teaching website: http://www.narst.org/publications/research/skill.cfm.

[25] Tamir, P. (1985). A meta-analysis of cognitive preference and learning. Journal of Research in Science Teaching, 22, 1-17. 